\title{
Audit Quality, Corporate Governance and Firm Characteristics in
}

\section{Nigeria}

\author{
Semiu Babatunde Adeyemi \\ Department of Accounting, University of Lagos \\ Lagos State, Nigeria \\ E-mail: sbaadeyemi@yahoo.co.uk \\ Temitope Olamide Fagbemi \\ Department of Accounting and Finance, University of Ilorin \\ Kwara State, Nigeria \\ E-mail: olamidefag@yahoo.com
}

\begin{abstract}
The major corporate collapses and related frauds which occurred in Nigeria and around the world have raised doubts about the credibility of the operating and financial reporting practices of quoted companies in Nigeria. This stirred a number of professional and regulatory organizations to recommend reforms that will improve transparency in financial reporting and thereby increase audit quality and corporate governance practices. Although evidence of corporate governance practices and audit quality exists from developed economies, very scanty studies have been conducted in Nigeria where corporate governance is just evolving. Therefore, this study provides evidence on corporate governance, audit quality, and firm related attributes from a developing country, Nigeria. Logistic regression was used in investigating the questions that were raised in the study. Findings from the study show that ownership by non-executive director has the possibility of increasing the quality of auditing. Evidence also exist that size of the company and business leverage are important factors in audit quality for companies quoted on the Nigerian Stock Exchange. The study suggests that the composition of non-executive directors as members of the board should be sustained and improved upon in order to enhance audit quality.
\end{abstract}

Keywords: Audit quality, Corporate governance, Ownership structure, Duality, Firm characteristics

\section{Introduction}

There has been a considerable debate in recent times concerning the need for strong corporate governance (McConomy and Bujaki, 2000), with countries around the world drawing up guidelines and codes of practice to strengthen governance (Cadbury, 1997, Corporate Governance Code of Nigeria, 2005). The rationale for this emphasis can be linked to increased concerns over the integrity of securities markets (International Federation of Accountants-IFAC, 2010; Millstein, 1999).

Good corporate governance by boards of directors is recognised to influence the quality of financial reporting, which in turn has an important impact on investor confidence (Levitt, 1998 and 2000). Studies have shown that good governance reduces the adverse effects of earnings management as well as the likelihood of creative financial reporting arising from fraud or errors (Beasley, 1996; Dechow, et al., 1996; McMullen, 1996). Traditionally, the external auditor has also played an important role in improving the credibility of financial information (Mautz and Sharaf, 1961; Wallace, 1980).

In recent times, a series of well-publicized cases of accounting improprieties in Nigeria (for example, such as is reported in relation to Wema Bank, NAMPAK, Finbank, and Springbank in Nigeria) has captured the attention of investors and regulators alike. The search for mechanisms to ensure reliable, high quality financial reporting has largely focused on the structure of audit quality. The auditing profession has been proactive in attempting to improve audit quality by issuing standards focused on discovery and independence. As a result, there has been a concerted effort to devise ways of enhancing independence (Corporate Governance Code of Nigeria, 2005; Blue Ribbon Committee, 1999). The profession has also responded to denigrations on audit quality. It emphasised that, by its nature, the inherent limitations of an audit make it impossible to eliminate the risk of audit failure (Ricchiute, 1998; IFAC, 2009). The effect of sound governance practices on the quality of financial reporting has recently received attention from researchers, particularly in the United States (McMullen, 1996; Beasley, 1996; 
Beasley, et al., 2000; Abbott, et al., 2000). The main focus of these studies is the relation between audit committees and fraudulent financial reporting, with results generally supporting a negative relation between an active audit committee and the likelihood of a company being cited for fraudulent reporting. While these results provide evidence from a strong and sophisticated capital market environment, very little research has been conducted in countries where capital markets are less developed and where governance mechanisms are still evolving. However, sound corporate governance practices are equally, if not more important, in countries that are attempting to gain credibility among global investors. This is particularly so in Nigeria as the country attempts to regain investor confidence following widely reported financial crises.

\subsection{Statement of the Problem}

The weakness of corporate governance is perhaps the most important factor blamed for the corporate failure consequences from the economics and corporate crises. There is much that can be done to improve the integrity of financial reporting through greater accountability, the restoration of resources devoted to audit function, and better corporate governance policies (Saudagaran, 2003). Concerns have also emerged about reduced audit quality. Economist (2004) noted that there are questions about the independence of the "Big 4" and suggested that concentration is lowering the quality of audits. Therefore, our study extends and contributes to the body of research using Nigerian data to investigate the likely impact of audit quality and governance related attributes. This study is motivated by the interest surrounding the appropriateness of reforms instituted by corporate governance code in Nigeria in response to the corporate failures, global best practice and their implied efficacy in the face of significant implementation and audit quality. We investigate empirically the relationship of attributes in the code in improving financial reporting quality.

\subsection{Objectives of the Study}

This study specifically identified the following objectives:

i. $\quad$ to examine board composition among the quoted companies Nigeria;

ii. to investigate the structure of board ownership of quoted companies in Nigeria;

iii. to examine institutional ownership of quoted companies in Nigeria;

iv. $\quad$ to identify the structure of the $\mathrm{CEO} /$ Chairmanship of quoted companies in Nigeria; and

v. to examine the relationship between board composition, ownership, institutional structures, CEO Chairmanship and firm characteristics on audit quality.

\subsection{Research Questions}

The main research problem was broken down into sub-problems stated as research questions, which guided the study. Attempts were made in the course of the research to resolve the following questions which were raised:

i. Does board ownership structure have any relationship with audit quality of quoted companies in Nigeria?

ii. Does institutional ownership structure affect audit quality of quoted companies in Nigeria?

iii. Is there a relationship between audit quality and each of CEO duality and firm characteristics of quoted companies in Nigeria?

\subsection{Research Hypotheses}

The null hypotheses stated below, were tested in order to provide answers to the research questions mentioned.

Hypothesis 1: There is no significant relationship between board independence and audit quality.

Hypothesis 2: There is no significant relationship between non-executive directors' ownership and audit quality.

Hypothesis 3: There is no significant relationship between executive directors' ownership and audit quality.

Hypothesis 4: There is no correlation between non-financial institutional ownership and audit quality.

Hypothesis 5: There is no significant relationship between financial institutional ownership and audit quality.

Hypothesis 6: CEO duality does not significantly correlate with audit quality.

Hypothesis 7: There is no significant relationship between firm characteristics and audit quality. 


\subsection{Significance of the Study}

The importance of auditing can be illustrated under the principal-agent relationship. The demand for external audits is directly related to the fact that it is the directors (the agents) who prepare the financial statements, which is primarily based on cost reasons. Therefore, this study is expected to provide useful insight into improving audit quality. This study contributes to the audit literature as it provides additional empirical evidence on the impact of the size of audit firm (big and non-big) on the level of audit quality. The study also reflects the quality of audit services between "big and non-big" audit firms in Nigeria. This study will be useful to stakeholders in the Nigerian Stock Exchange (NSE) as it provides evidence on the relationship between audit quality and the reform instituted by them in formulating the Code of Corporate Governance for listed companies in Nigeria.

\subsection{Scope of the Study}

This study is premised on the appraisal of audit quality in Nigeria. Therefore, data on corporate organisations in Nigeria were sought in providing answers to the problems and questions that have been raised in this research work. The study focuses companies quoted on the floor of the Nigerian Stock Exchange (NSE).

The remainder of this paper is organised as follows: Section II discusses the relevant literature including audit quality, audit committee and corporate governance, board structure, ownership structure, and CEO duality and audit quality. The methodology adopted to lend empirical weight to the findings was outlined in Section III. Section IV provides the results while Section V concludes the paper.

\section{Literature Review}

\subsection{Overview of Audit Quality}

The various changes in accounting, financial reporting and auditing were all designed to provide protection to investors. This is being achieved by imposing a duty of accountability upon the managers of a company (Crowther and Jatana, 2005). In essence, auditing is used to provide the needed assurance for investors when relying on audited financial statements. More precisely, the role of auditing is to reduce information asymmetry on accounting numbers, and to minimize the residual loss resulting from managers' opportunism in financial reporting. Effective and perceived qualities (usually designated as apparent quality) are necessary for auditing to produce beneficial effects as a monitoring device. The perceived audit quality by financial statements users is at least as important as the effective audit quality. Conceptually, DeAngelo (1981) defined audit quality as the market-assessed joint probability that the auditor discovers an anomaly in the financial statements, and reveals it. Agency theory recognizes auditing as one of the main monitoring mechanisms to regulate conflicts of interest and cut agency costs. Therefore, assuming a contracting equilibrium in the monitoring policy, a change in the intensity of agency conflicts should similarly involve a change in the acceptable quality of auditing.

\subsection{Audit Committee and Corporate Governance}

Literature suggests that a valuable audit committee should play an important role in strengthening the financial controls of a business entity (Collier, 1993; English, 1994; Vinten and Lee, 1993). A number of studies have found that companies with an audit committee, particularly when that committee is active and independent, are less likely to experience fraud (Beasley, et al., 2000; Abbott, et al., 2000; McMullen, 1996) and other reporting irregularities (McMullen, 1996; McMullen and Raghunandan, 1996). Findings also suggest that audit committees are effective in reducing the occurrence of earnings management that may result in misleading financial statements (Defond and Jiambalvo, 1991; Dechow, et al., 1996; Peasnell, et al., 2000).

Audit committee is also expected to enhance the effectiveness of both internal and external auditors (Simnett, et al., 1993). However, Cohen, et al. (2000) report that a number of audit practitioners involved in exploratory interviews expressed concern over the effectiveness of audit committees, with some partners suggesting that audit committees are not powerful enough to resolve conflicts with management. It is generally agreed that, for an audit committee to be effective, a majority, if not all members, should be independent (Cadbury, 1992) and they should have an understanding of accounting, auditing and control issues (Cohen, et al., 2000; Goodwin and Seow, 2000; Hughes, 1999; Lear, 1998). Literature also linked audit quality with the boards of directors, and the audit committees of boards of directors. This shows that audit quality is positively related to boards and audit committees when they are more independent (that is, higher number of outside directors). Carcello and Neal (2000) show that auditors are more likely to issue going concern reports in the presence of more independent boards and are less likely to be fired by the company following the issuance of a going concern audit report. 


\subsection{Board Structure and Audit Quality}

The linkage between the board and the quality of audit services performed may be formal or informal. In terms of formal linkage, the board of directors typically collaborates with management in selecting the external auditor, often subject to shareholder ratification. Since the auditor is to look to the board as its client, it is reasonable to expect the board to review the overall planned audit scope and proposed audit fee (Blue Ribbon Committee 1999; Public Oversight Board 1994). The board also may influence audit quality through informal means. The board's commitment to vigilant oversight may signal to management and the auditor that the expectations placed on the audit firm are very high. If the auditor understands that the client (that is, the board) is particularly of high quality and demanding, the auditor may perform a higher-quality audit so as not to disappoint the client and jeopardize the relationship. Given the board's oversight of the financial reporting and audit processes, as well as prior literature linking certain board characteristics to adverse financial reporting outcomes (Beasley, 1996; Dechow, et al. 1996), this current study explores the link between board characteristics and audit quality in Nigeria.

Fama and Jensen (1983) have theorized that the board of directors is the best control mechanism to monitor actions of management. The study explored board independence based on the agency theory. Studies of O'Sullivan (2000) and Salleh, et al. (2006) found that the proportion of non-executive directors had a significant positive impact on audit quality. They suggested that non-executive directors encouraged more intensive audits as a complement to their own monitoring role while the reduction in agency costs expected through significant managerial ownership resulted in a reduced need for intensive auditing.

\subsection{Ownership Structure and Audit Quality}

The relationship between outside shareholders and managers is marked by moral hazard and opportunism, which result from information asymmetry. The social role of financial reporting increases with the separation of ownership and control (Wan, et al. 2008). Indeed, accounting numbers are essential indicators to assess managers' performance. However, the discretionary power of managers over the accounting policy being important in firms with diffused ownership, their propensity to manipulate the outputs of the accounting process is higher. In contrast to the directors' ownership, an institutional ownership is an investment from a group of outside investors or investment from a certain institution. The percentage of ownership from institution is normally higher than individual investor. It is assumed that institutional investors have more influence than other individual investors. With the high portion of ownership, institutional ownership has the importance of monitoring role in the process auditing. It is rational that institutional investors demand high quality information from the company. Kane and Velury (2002) observed that the greater the level of institutional ownership, the more likely it is that a firm purchases audit services from large audit firm in order to ensure high audit quality.

For the purpose of the current study, institutional ownership can be separated into two main categories which are financial institutional and non-financial institutional ownership. The main difference between both groups is related to core business of investor. The core business of financial institutions is investment but not for non-financial institutions. However, both institutions are expected not to have different influence on audit quality. Mitra, et al. (2007) found that diffused institutional ownership was significantly and positively related to audit fees. The study linked their finding to either institutional investor demand for the purchase of high quality audit services as safeguard against fraudulent financial reporting or firms' endeavour to purchase high quality audits to attract institutional investment in common stock. It is expected that the portion of institutional ownership will have impact on audit quality of the company.

\subsection{CEO Duality and Audit Quality}

This study also intended to discover the relationship between the CEO duality and audit quality. The CEO duality refers to non-separation of roles between Chief Executive Officer (CEO) and the Chairman of the board. In the normal situation, boards with CEO duality are perceived ineffective because a conflict of interest may arise. This is often attributed to the nature of family owned business in developing countries. Yemark (1996) posits that large companies that have separate persons for both functions normally trade at higher price and have higher return on assets and cost efficiency ratios (Pi and Timme, 1993).

\section{Methodology}

This study is an explanatory study. Saunders et al., (2007) stated that studies that establish causal relationships between variables may be termed explanatory studies. They emphasized that this has to do with studying a situation or a problem in order to explain the relationships between variables. This research strategy was considered necessary because of its ability to view comprehensively and in detail the major questions raised in 
the study. Since this study is on audit quality of quoted companies in Nigeria, population of the study is made up of companies listed on the floor of the Nigerian Stock Exchange (NSE). A sample consisting of companies listed on the NSE was considered a good representation of quoted companies in Nigeria since the ultimate test of a sample design is how well it represents the characteristics of the population it purports to represent (Emory \& Cooper, 2003). A sample of fifty-eight (58) audited financial reports of quoted companies for the period 2007 year-end was used. Therefore, respondents cut across public limited companies that were listed on the floor of the NSE.

The data collected were analysed using both descriptive and inferential statistics. The descriptive method described information relating to audit firm (categorised into big 4 and non-big 4) and CEO duality. The study used frequency count, mean, standard deviation, minimum and maximum values of variables. Information relating to the composition of outside director members of board, audit committee composition, board ownership, CEO duality and firm characteristics (which are, company size, business complexity, institutional ownership and leverage) were collected from company annual reports.

\subsection{Dependent and Independent Variables}

Independent variables of the study were audit committee, CEO duality, business complexity, leverage, executive directors' ownership, non-executive directors' ownership, financial institution ownership, non-financial institution ownership and board independence. The dependent variable was audit quality which was measured by size of audit firm (big and non-big).

\subsection{Conceptual Underpinnings of the Linear Probability Model}

The hypotheses formulated for this study were tested with the use of logistic regression. This was used to examine the relationship between dependent and independent variables. According to Field (2000), logistic regression is multiple regression but with an outcome variable that is a categorical dichotomy and predictor variables that are continuous or categorical. The logistic regression for this study takes the form:

$$
\begin{aligned}
\text { AUDITQUAL }= & \beta_{0}+\beta_{1} \text { BODINDEP }+\beta_{2} \text { EDOWN }+\beta_{3} \text { NEDOWN }+ \\
& \beta_{4} \text { FINOWN }+\beta_{5} \text { NFINOWN }+\beta_{6} \text { LEVERAGE }+ \\
& \beta_{7} \text { COMPLEXITY }+\beta_{8} \text { SIZE }+\beta_{9} \text { CEOSHIP }+\varepsilon
\end{aligned}
$$

\subsubsection{Definition of Variables}

The dependent variable is audit quality. This variable is dichotomous in nature. Size of audit firm (big 4 and non-big 4) was used as proxy for audit quality. Audit quality was set equal to one (1) if the information obtained from companies audited reports show that it is audited by one of the "big 4" audit firms (KPMG; Ernst and Young; Akintola Williams Delloitte; PWC), otherwise zero (0). This operationalization follows the approach used in Kane and Velury (2002) where big audit firms are assumed to have quality audit services than other smaller audit firms.

The choice of the independent variables was informed by previous studies (Beasley and Petroni, 2001; Carcello, et al., 2002; Salleh, et al., 2006; Wan, et al., 2008 and Mitra, et.al., 2007). Board independence (BODINDEP) was measured through the composition of non-executives in the board of directors in form of percentage. The non-executive directors' ownership (NEDOWN) and executive directors' ownership (EDOWN) were based on percentage of share owned in relation to the issued capital of the company. Furthermore, financial institution (FINOWN) and non-financial institution ownership (NFINOWN) were measured using percentage of shares owned in relation to the issued capital of the company. The variable of CEO duality (CEOSHIP) was a dichotomous variable that operated as one (1) if the position of Chairman and Chief Executive Officer is occupied by same person and zero $(0)$ if otherwise. The inclusion of other variables like size of the company (SIZE), business complexity (COMPLEXITY) and leverage of the company (LEVERAGE) was based on the findings of Kane and Velury (2002) \& Wan et al. (2008). The studies noted that these variables have significant relationships with audit quality. The size of the company was measured by total asset owned by each of the companies while business complexity was measured by the summation of total accounts receivable and total inventory divided by total asset. Furthermore, leverage was measured by total debts divided by total assets. Upon improvements of the logistic regression (equation i), it was observed that audit committee independence has collinearity problem while tests for outliers suggested the removal of some variables which then led to the final model as given below:

$$
\text { AUDITQUAL }=\beta_{0}+\beta_{1} \text { NEDOWN }+\beta_{4} \text { FINOWN }+\beta_{6} \text { LEVERAGE }+\beta_{8} \text { SIZE }+\varepsilon
$$




\section{Data Analysis and Presentation of Results}

This section of the study is devoted to presenting the results of the analysis performed on the data collected to test the propositions made in the study and answer the research questions. Analyses were carried out with the aid of the Statistical Package for Social Sciences, (SPSS Version 15.0).

Table 4.1 shows that seventy-four percent (74\%) of companies sampled are audited by the big 4 audit firms while Table 4.2 also shows that ninety five percent $(95 \%)$ of the companies sampled have separate people occupying the position of Chairman and CEO. Table 4.3 provides the mean, median, minimum, maximum and standard deviation of the variables in the study.

\subsection{Analysis of Logistic Regression}

The analysis of logistic regression was done to test the hypotheses proposed for this study. The test of multicollinearity was done before analysing the logistic regression model. Audit committee independence (AUDINDEP) was found to have multicollinearity problem, hence, it was not included in subsequent analysis. Field (2000) noted that this test is necessary because multicollinearity can affect the parameters of a regression model. The tolerance value and VIF value appeared normal with values ranging between 0.555 and 0.883 for collinearity tolerance and 1.133 and 1.802 for collinearity VIF. Menard (1955) suggested that a tolerance value less than 0.1 almost certainly indicates a serious collinearity problem. It was noted that tolerance values are higher than 0.1. Furthermore, Myers (1990) also suggested that a VIF value greater than 10 calls for concern, however, in the current study, the VIF values are less than 10.

The regression carried out suggests that the model correctly classifies $74.1 \%$ of the companies surveyed (Table 4.4). The computed constant $\left(\beta_{0}\right)$ value of the model is equal to 1.053 . There are indications from Table 4.5 that the -2LL has reduced from 66.307 to 40.260 with the inclusion of additional variables to the constant. $86.2 \%$ of the samples collected are correctly predicted as shown in Table 4.4. Table 4.6 shows that the values of Cox \& Snell R Square and Nagelkerke R Square are 0.362 and 0.531 respectively. Hosmer and Lemeshow test also indicates the goodness-of-fit of the model with chi-square value of 12.717 with $p$-value $>0.05$. Therefore, the model adequately describes the data.

The study also suggests from Table 4.5 that BODINDEP, FINOWN, NFINOWN and CEOSHIP have no significant correlation with audit quality although there is a positive correlation in all of them except CEOSHIP. However, governance variable such as NEDOWN and EDOWN have significant correlation with audit quality. This is evident with $p$-value $<0.05$ in both variables.

Results from variables representing firm characteristics such as SIZE and LEVERAGE have positive relationship with audit quality. While this relationship is significant for SIZE at p-value of 0.004 it is only significant at 0.10 level for LEVERAGE with a p-value of 0.80 . Therefore it can be inferred that there is a significant positive relationship between the size of a company and the choice of auditor or the level of audit quality of the firm. Hence, other firm characteristics like business leverage and business complexity are not significant at 0.05 level. For example, the findings suggest that there is a negative relationship between audit quality and business complexity and institutional ownership, though not really a significant relationship.

\section{Conclusion}

The aim of this research was to empirically examine the effective components of corporate governance in Nigerian quoted companies and its relationship with audit quality. In achieving this aim, the study obtained data on variables which were believed to have relationship with audit quality. These variables included COMPLEXITY, SIZE, LEVERAGE, BODINDEP, NEDOWN, EDOWN, FINOWN, NFINOWN and CEOSHIP. On the basis of these variables, hypotheses were postulated.

Results from the study indicate that non-executive directors' ownership, SIZE and LEVERAGE significantly have relationship with audit quality. However, all the other variables that were not found to have significant relationship still had correlation with audit quality at certain levels (Table 4.7). Therefore, this study recommends that the composition of non-executive directors as members of the board should be sustained and improved upon. Furthermore, this study may be improved upon by including more variables that may affect audit quality.

\section{References}

Abbott, L. J., Park, Y., \& Parker, S. (2000). The effects of audit committee activity and independence on corporate fraud. Managerial Finance, 26, 55-67 
Beasley, M. S. (1996). An empirical analysis of the relation between the board of director composition and financial statement fraud. Accounting Review, 71(10), 443-465

Beasley, M. S., \& Petroni, K. R. (2001). .Board independence and audit-firm type. Auditing, 20, 97-114

Beasley, M. S., Carcello, J.V., \& Hermanson, D.R. (2000). Fraudulent financial reporting: 1987-1997, An analysis of U.S. public companies. New York: Committee of Sponsoring Organizations of the Treadway Commission (COSO)

Blue Ribbon Committee. (1999). Report and recommendations of the Blue Ribbon Committee on improving the effectiveness of corporate audit committee, New York: NYSE and NASD.

Cadbury Committee. (1992). Report of the Committee on the Financial Aspects of Corporate Governance. London: Gee and Company Ltd.

Carcello, J. V., Hermanson, D. R., Neal, T. L., \& Riley, R. A. Jr. (2002). Board characteristics and audit fees. Contemporary Accounting Research, 19(3), 365-384

Carcello, J.V., \& Neal, T.L. (2000). Audit committee composition and auditor reporting. Accounting Review, 75, 453-467

Cohen, J. R., \& Hanno, D. M. (2000). Auditors' consideration of corporate governance mid management control philosophy in preplanning and planning judgments. Auditing: A Journal of Practice \& Theory, 19(2), $133-146$.

Collier, P. A. (1993). Audit committee in major UK companies. Managerial Auditing Journal, 18(3), 25-30

Corporate Governance Code of Nigeria. (2005). Lagos: SEC

Crowther, D., \& Jatana R. (2005). Agency theory: a cause of failure in corporate governance. In: D. Crowther and R. Jatana (eds.) International dimensions of corporate social responsibility, 1, 135-152.

DeAngelo, L. E. (1981). Auditors size and audit quality. Journal of Accounting and Economics, 3, 183-199

Dechow, P.M., Sloan, R.G., \& Sweeney, A.P. (1996). Causes and consequences of earnings manipulation: An analysis of firms subject to enforcement actions by the SEC. Contemporary Accounting Research, 13(1), 1-36

DeFond, M. L., \& Jiambalvo, J. (1991). Incidence and circumstances of accounting errors. The Accounting Review, 66(7), 643-655

Economist. (2004). Special Report: The Future of Auditing, November 20, 71 - 73

Emory, C. W., \& Cooper. D. R. (1991). Business research methods. (4 ${ }^{\text {th }}$ ed.). Illionois: Richard D. Irwin Inc.

English, L. (1994). Making audit committees work. Australian Accountant, 64(3), 10-18

Fama, E. K., \& Jensen, M. C. (1983). Separation of ownership and control. Journal of Law \& Economics 26(6), 301-325

Field, A. (2000). Discovering statistics: Using SPSS for Windows. London: Sage Publications

Goodwin, J., \& Seow, J. L. (2000). The influence of corporate governance mechanisms on the quality of financial reporting and auditing: perceptions of auditors and directors in Singapore. Journal of Accounting and Finance, 42(3), 195-224

Hughes, R. (1999). The rise and rise of the audit committee. Accountancy, 123(1266): 59

International Federation of Accountants - IFAC. (2010). IFAC Comment Letter: Transparency of Firms that Audit Public Companies: Consultation Report, [Online] Available: http://web.ifac.org/publications/ifac-policy-position-papers-reports-and-comment-letters/comment-letters\#ifac-c omment-letter-transp on 29/01/2010

International Federation of Accountants- IFAC. (2009). Rebuilding Public Confidence In Financial Reporting: An International Perspective, [Online] Available: $\mathrm{http}$ //web.ifac.org/publications/ifac-policy-position-papers-reports-and-comment-letters/reports-1\#developments -in-the-financial-reporting-supply-chain-results-from-a-global-study-among-ifac-member-bodies on 7/01/2010

Kane, G. D., \& Velury, U. (2002). The role of institutional ownership in the market for auditing services: an empirical investigation. Journal of Business Research, 1-8

Lear, R.W. (1998). Auditing the audit committee. Chief Executive, 11: 1 
Levitt, A. (1998). The numbers game. Remarks delivered at the NYU Center for Law and Business. New York, NY, September 28. [Online] Available: http://www.sec.gov/news/speech/speecharchive/1998/spch220.txt on $12 / 10 / 2009$

Levitt, A. (2000). Speech by SEC Chairman: Remarks Before the Conference on the Rise and Effectiveness of New Corporate Governance Standards, Federal Reserve Bank, New York, [Online] Available: http://www.sec.gov/news/speech/spch449.htm on 19/10/2009

Mautz, R. K., \& Sharaf. H.A. (1961). The Philosophy of Auditing. American Accounting Association. Sarasote McConomy, B., \& Bujaki, M. (2000). Corporate Governance: Enhancing Shareholder Value. CMA Management, 74(8), 10-13

McMullen D.A. (1996). Audit committee performance: an investigation of the consequences associated with audit committees. Auditing: A Journal of Practice \& Theory, 15(1), 87-103

McMullen, D.A., \& Raghunandan, K. (1996). Enhancing audit committee effectiveness. Journal of Accountancy, $182,79-81$

Menard, S. (1995). Applied logistic regression analysis. Sage University paper series on qualitative applications in the social sciences, 07-106. Thousands Oaks, CA: Sage.

Millstein, I. M. (1999). Introduction to the Report and Recommendations of the Blue Ribbon Committee on Improving the Effectiveness of Corporate Audit Committees. Business Lawyer, 54(3), 1097-1111

Mitra, S., Hossain, M., \& Deis, D.R. (2007). The empirical relationship between ownership characteristics and audit fees. Rev Quant Finance Acc, 28, 257-285.

Myers, R. (1990). Classical and modern regression with applications (2 ${ }^{\text {nd }}$ ed.). Boston, MA: Duxbury.

O'Sullivan, N. (2000). The impact of board composition and ownership on audit quality: evidence from large UK companies. The British Accounting Review, 32(4), 397- 414

Peasnell, K. V., Pope, P. F., \& Young, S. (2000). Board monitoring and earnings management: do outside directors influence abnormal accruals?. Lancaster University Working Paper. [Online] Available www.http://papers.ssrn.com/sol3/papers.cfmabstract_id249557

Pi, L., \& Timme, S. (1993). Corporate Control and Bank Efficiency. Journal of Banking and Finance, 17(2), 515-530

Public Oversight Board. (1994). Strengthening the professionalism of the independent auditor. Stamford, CT: POB.

Ricchiute, D.N. (1998). Evidence, memory, and causal order in a complex audit decision task. Journal of Experimental Psychology: Applied, 4(1), 3-15

Salleh, Z., Stewart, J., \& Manson, S. (2006). The Impact of Board Composition and Ethnicity on Audit Quality: Evidence from Malaysian Companies. Malaysian Accounting Review, 5(2), 61-83

Saudagaran, S. M. (2003). The Accounting World Post-Enron, Tyco, Vivendi, Worldcom, Xerox...: Reflections on Being Part of the Solution. Malaysian Accounting Review, 2(1), 2-12

Saunders, M., Lewis, P., \& Thornhill, A. (2003). Research methods for business students, (3 ${ }^{\text {rd }}$ ed.). England: Pearson Education Limited.

Simnett, R., Green, W., \& Roebuck, P. (1993). Disclosure of Audit Committees by Public Companies in Australia 1988- 1990. Australian Accounting Review, 3(1), 45-50

SPSS 15 for Windows Evaluation Version Release 15.0 (2006)

Vinten, G., \& Lee, C. (1993). Audit committees and corporate control. Managerial Auditing Journal, 8(3), 11-24

Wallace, W.A., (1980). The Economic role of the audit in free and regulated markets, Touche Ross \& Co. Aid to Education Program

Wan, Z.W.A., Shahnaz, I., \& Nurasyikin, J. (2008). The impact of board composition, ownership and CEO duality on audit quality. Malaysian Accounting Review, 7(2), 1-22

Yermack, D. (1996). Higher Market Valuation of Companies with Small Boards of Directors. Journal of Financial Economics, 40(2), 185-212 
Table 4.1. Audit Quality

\begin{tabular}{|l|l|l|l|l|}
\hline & Frequency & Percent & Valid Percent & Cumulative Percent \\
\hline NON BIG 4 AUDITOR & 15 & 25.9 & 25.9 & 25.9 \\
\hline BIG 4 AUDITOR & 43 & 74.1 & 74.1 & 100.0 \\
\hline Total & 58 & 100.0 & 100.0 & \\
\hline
\end{tabular}

\section{Source: Research Survey}

Table 4.2. Ceo Duality

\begin{tabular}{|l|l|l|l|l|}
\hline & Frequency & Percent & Valid Percent & $\begin{array}{l}\text { Cumulative } \\
\text { Percent }\end{array}$ \\
\hline CEODuality & 55 & 94.8 & 94.8 & 94.8 \\
\hline NO CEODuality & 3 & 5.2 & 5.2 & 100.0 \\
\hline
\end{tabular}

\section{Source: Research Survey}

Table 4.3. Descriptive Statistics

\begin{tabular}{|l|l|l|l|l|l|}
\hline & $\mathbf{N}$ & $\mathbf{M i n}$ & $\mathbf{M a x}$ & Mean & Std. Deviation \\
\hline Audit Quality(AUDITQUAL) & 58 & 0 & 1 & .74 & .442 \\
\hline CEO duality (CEOSHIP) & 58 & 0 & 1 & .05 & .223 \\
\hline Executive directors' ownership(EDOWN) & 58 & .00 & .85 & .0619 & .13696 \\
\hline Non-executive directors' ownership(NEDOWN) & 58 & .00 & .45 & .0471 & .09418 \\
\hline Business Leverage (LEVERAGE) & 58 & .08 & 1.41 & .6136 & .24905 \\
\hline Audit Committee independence(AUDINDEP) & 58 & .00 & .00 & .0000 & .00000 \\
\hline Business Size (SIZE) & 58 & 5.36 & 9.08 & 7.0750 & .90255 \\
\hline Board Independence (BODINDEP) & 58 & .00 & 1.00 & .1207 & .32861 \\
\hline Financial Institution Ownership(FINOWN) & 58 & .00 & .55 & .0696 & .11786 \\
\hline Non-financial Institution Ownership(NFINOWN) & 58 & .00 & .88 & .2673 & .25647 \\
\hline Business Complexity(COMPLEXITY) & 58 & .02 & .99 & .3908 & .23778 \\
\hline
\end{tabular}

\section{Source: Research Survey}

Table 4.4. Classification Table (a, b)

\begin{tabular}{|c|c|c|c|c|c|}
\hline \multicolumn{3}{|c|}{ Observed } & \multicolumn{3}{|c|}{ Predicted } \\
\hline & & & \multicolumn{2}{|c|}{ AUDITQUAL } & \multirow[b]{2}{*}{$\begin{array}{c}\text { Percentage } \\
\text { Correct }\end{array}$} \\
\hline & & & $\begin{array}{c}\text { NON BIG } 4 \\
\text { AUDITOR }\end{array}$ & $\begin{array}{c}\text { BIG } 4 \\
\text { AUDITOR }\end{array}$ & \\
\hline \multirow[t]{3}{*}{ Step 0} & AUDITQUAL & NON BIG 4 AUDITOR & 0 & 15 & .0 \\
\hline & & BIG 4 AUDITOR & 0 & 43 & 100.0 \\
\hline & Overall Percentage & & & & 74.1 \\
\hline \multirow[t]{3}{*}{ Step 1} & AUDITQUAL & NON BIG 4 AUDITOR & 8 & 7 & 53.3 \\
\hline & & BIG 4 AUDITOR & 1 & 42 & 97.7 \\
\hline & Overall Percentage & & & & 86.2 \\
\hline
\end{tabular}

a Constant is included in the model. b The cut value is .500

Source: Research Survey 
Table 4.5. Iteration History (a,b,c,d)

\begin{tabular}{|ll|r|}
\hline Iteration & & \multicolumn{1}{|c|}{$\begin{array}{c}-2 \text { Log } \\
\text { likelihood }\end{array}$} \\
\hline Step 1 & 1 & 48.238 \\
& 2 & 42.010 \\
& 3 & 40.391 \\
& 4 & 40.261 \\
& 5 & 40.260 \\
& 6 & 40.260 \\
7 & 40.260 \\
\hline
\end{tabular}

a Method: Enter

b Constant is included in the model.

c Initial -2 Log Likelihood: 66.307

d Estimation terminated at iteration number 7 because parameter estimates changed by less than .001 .

\section{Source: Research Survey}

Table 4.6. Results from Logistic Regression

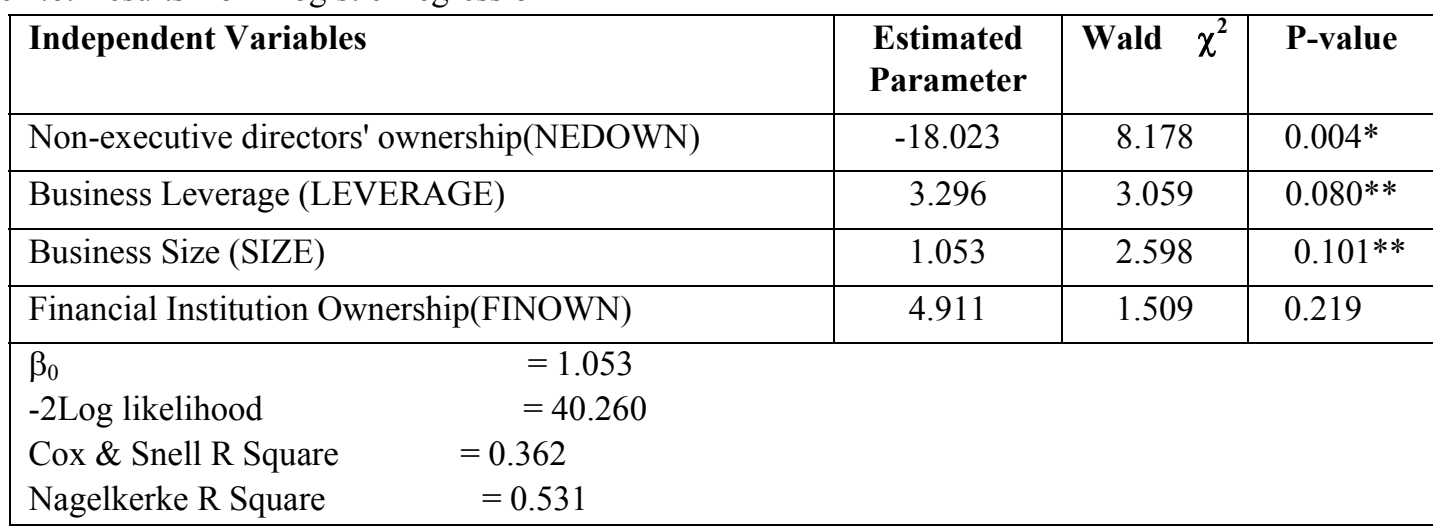

** Correlation is significant at the 0.10 level

* Correlation is significant at the 0.01 level

Source: Research Survey

\begin{tabular}{|c|c|c|c|c|c|c|c|c|c|c|c|}
\hline & & AUDITQUAL & BODINDEP & COMPLEXITY & SIZE & LEVERAGE & NEDOWN & EDOWN & FINOWN & NFINOWN & CEOSHIP \\
\hline \multirow[t]{2}{*}{ AUDITQUAL } & Pearson Correlation & 1 & .219 & -.109 & $.375(* *)$ & .241 & $-.495(* *)$ & $-.409(* *)$ & .061 & .237 & -.218 \\
\hline & Sig. (2-tailed) & & .099 & .414 & .004 & .068 & .000 & .001 & .647 & .073 & .101 \\
\hline \multirow[t]{2}{*}{ BODINDEP } & Pearson Correlation & & 1 & -.224 & $.546\left({ }^{* *}\right)$ & $.266(*)$ & -.109 & -.120 & -.117 & -.062 & -.087 \\
\hline & Sig. (2-tailed) & & & .091 & .000 & .044 & .415 & .371 & .382 & .642 & .518 \\
\hline \multirow[t]{2}{*}{ COMPLEXITY } & Pearson Correlation & & & 1 & -.163 & $.262(*)$ & .211 & .069 & -.114 & .172 & -.103 \\
\hline & Sig. (2-tailed) & & & & .220 & .047 & .112 & .607 & .393 & .196 & .442 \\
\hline \multirow[t]{2}{*}{ SIZE } & Pearson Correlation & & & & 1 & $.325\left(^{*}\right)$ & -.250 & -.189 & .030 & -.171 & -.145 \\
\hline & Sig. (2-tailed) & & & & & .013 & .058 & .156 & .823 & .200 & .279 \\
\hline \multirow[t]{2}{*}{ LEVERAGE } & Pearson Correlation & & & & & 1 & -.078 & .019 & -.210 & -.004 & .011 \\
\hline & Sig. (2-tailed) & & & & & & .560 & .887 & .113 & .974 & .936 \\
\hline \multirow[t]{2}{*}{ NEDOWN } & Pearson Correlation & & & & & & 1 & .154 & -.021 & $-.307(*)$ & $.308(*)$ \\
\hline & Sig. (2-tailed) & & & & & & & .248 & .878 & .019 & .019 \\
\hline \multirow[t]{2}{*}{ EDOWN } & Pearson Correlation & & & & & & & 1 & .084 & -.182 & .221 \\
\hline & Sig. (2-tailed) & & & & & & & & .531 & .170 & .096 \\
\hline \multirow[t]{2}{*}{ FINOWN } & Pearson Correlation & & & & & & & & 1 & -.248 & $.386(* *)$ \\
\hline & Sig. (2-tailed) & & & & & & & & & .061 & .003 \\
\hline \multirow[t]{2}{*}{ NFINOWN } & Pearson Correlation & & & & & & & & & 1 & -.197 \\
\hline & Sig. (2-tailed) & & & & & & & & & & .139 \\
\hline \multirow[t]{2}{*}{ CEOSHIP } & Pearson Correlation & & & & & & & & & & 1 \\
\hline & Sig. (2-tailed) & & & & & & & & & & \\
\hline
\end{tabular}


Appendix: List of Companies Surveyed

1. 7 UP Bottling Company

2. Academy Press PLC

3. Access Bank

4. Adswitch Plc

5. Afprint

6. Afribank Nigeria Plc

7. African Petroleum Plc

8. AG Leventis (Nigeria) Plc

9. Aiico Insurance PLC

10. Aluminium Extrusion Industries Plc

11. Ashaka Cement PLC

12. Avon Crowncaps \& Containers Plc

13. B.O.C. Gases plc

14. Beta Glass Company

15. Big Treat plc

16. C \& I Leasing Plc

17. Cadbury Nigeria PLC

18. Cap Plc.

19. Cement Company Of Northern Nigeria Plc

20. Chevron Oil Company

21. Continental Reinsurance Plc

22. Cornerstone Insurance Company Plc

23. Costain (W.A.) Plc

24. Crusader Insurance Plc

25. Dangote Flour Mills

26. Dangote Sugar Refineries

27. DN Meyer PLC

28. Evans Medical Plc

29. First Bank Of Nigeria PLC

30. First City Monument Bank Limited

31. Flour Mills Nigeria PLC

32. Glaxosmithkline Consumer Nigeria Plc

33. Guaranty Trust Bank Plc

34. Guinea Insurance Plc

35. Guinness Nigeria plc

36. Ikeja Hotels Plc

37. Intercontinental Bank Plc

38. International Energy Insurance Company Limited
39. Ipwa Plc.

40. Japaul \& Maritime Services Plc

41. Julius Berger Nigeria Plc

42. Lafarge Cement WAPCO Nigeria

43. Lasaco Assurance Plc

44. Linkage Assurance Plc

45. Longman Nigeria Plc

46. Nigeria Enamelware Company Plc

47. Nigerian Breweries Plc

48. Thomas Wyatt Nigeria Plc

49. Trans-Nationwide Express Plc

50. UACN Property Development Plc

51. Unic Insurance Plc

52. Unilever Nigeria Plc

53. United Bank for Africa Plc

54. University Press

55. UTC Nigeria Ltd.

56. Vitafoam Nigeria

57. Wema Bank PLC

58. Zenith Bank PLC

44. Linkage Assurance Plc

45. Longman Nigeria Plc

46. Nigeria Enamelware Company Plc

47. Nigerian Breweries Plc

48. Thomas Wyatt Nigeria Plc

49. Trans-Nationwide Express Plc

50. UACN Property Development Plc

51. Unic Insurance Plc

52. Unilever Nigeria Plc

53. United Bank for Africa Plc

54. University Press

55. UTC Nigeria Ltd.

56. Vitafoam Nigeria

57. Wema Bank PLC

58. Zenith Bank PLC 